\title{
How suitable are available pharmaceuticals for the treatment of sexually transmitted diseases? 1: Conditions presenting as genital discharges
}

\author{
R. R. WILLCOX \\ From St Mary's Hospital, London and King Edward VII Hospital, Windsor
}

SUMMARY The relative prevalence of sexually transmitted diseases and the agents available for the treatment of these diseases commonly presenting as genital discharges-namely, gonorrhoea, candidosis, trichomoniasis, and non-specific genital infection-are reviewed. The many agents that are active against gonorrhoea are listed, but none is ideal. Penicillin, in spite of its allergic side effects, has remained the drug of choice for 25 years because it is cheap, easily obtained, lacks toxicity even in pregnancy, and is effective. Its use is now threatened by the emergence of some strains that are able to produce penicillinase. At present the policy is to obtain the best results from penicillin while these are acceptable, but the clinician in some countries is badly served by the availability of procaine penicillin in aqueous suspension. There is a need for an effective penicillin or cephalosporin that is penicillinase resistant and cheap. Cefuroxime offers considerable hope but it is likely to be expensive in the immediate future.

There are many preparations for the local treatment of candidosis. The confidence expressed by the manufacturers in recommending a three-day treatment is, it is hoped, based on a superior product Nevertheless there is a need for a safe systemically absorbed fungicide which could be used orally, or some substance that could render the vagina an inhospitable environment for the organism.

In the treatment of trichomoniasis the pharmaceutical industry in providing substances more than $90 \%$ effective in a single dose has done all that can be expected. Any further advances lie in the field of human behaviour rather than pharmaceutical research.

In the treatment of non-specific genital infection the needs are more of research than of therapy. More knowledge is required of the cause of the condition and the relative role of contending pathogens, and of the results of treatment of patients and contacts in which Chlamydia or other suspect pathogens have been isolated.

\section{Introduction}

The causative agents of the sexually transmitted diseases are: spirochaetes (syphilis), other bacteria (gonorrhoea, soft sore, granuloma inguinale), Chlamydia (lymphogranuloma venereum, nongonococcal urethritis), viruses (condylomata acuminata or venereal warts, molluscum contagiosum, and herpes genitalis), protozoa (trichomoniasis and occasionally amoebiasis), fungi (candidosis), and parasites (scabies, pediculosis pubis).

Presented at the Sandoz Research Institute, Vienna, 4 May 1977 Address for reprints: R. R. Willcox, MD, FRCP, Consultant Venereologist, St Mary's Hospital, London W2.

Received for publication 17 May 1977
In addition there are numerous other organisms known to be sexually transmitted some of which are known or suspected pathogens including mycoplasmas, group B streptococci, Haemophilus vaginalis, cytomegalovirus, and the virus of hepatitis B (Australia antigen). In a number of studies it has been shown that hepatitis $B$, which can have serious results, occurs significantly more often in homosexual than in heterosexual men.

No longer then, can the scope of the venereologist be limited to providing the same drug for two diseases-syphilis and gonorrhoea.

In this paper the prevalence of the sexually transmitted diseases and the current state of treatment and prophylaxis are considered. In order to do 
this in a meaningful way the prevalence of those sexually transmitted diseases for which statistical data are available are compared in both sexes with those of gonorrhoea (stabilised at a 100). As few statistical data are available the calculations of relative prevalence will be based on the reported statistics for England and Wales.

The relative prevalence of the various classified sexually transmitted diseases seen in the venereal disease clinics of England and Wales in the two sexes, related to gonorrhoea expressed as 100 , are shown in Table 1.

Table 1 Percentage of other sexually transmitted diseases in relation to gonorrhoea (England and Wales 1974)

\begin{tabular}{lll}
\hline Disease & Men & Women \\
\hline Gonorrhoea & 100 & 100 \\
& $(38466$ cases) & (21288 cases) \\
Non-specific genital infection & 185 & 71 \\
Candidosis & 14 & 130 \\
Trichomoniasis & 4 & 85 \\
Condylomata acuminata & 33 & 30 \\
Pediculosis pubis & 10 & 7 \\
Herpes genitalis & 9 & 8 \\
Total syphilis & 7 & 4 \\
Scabies & 6 & 1 \\
Primary and secondary syphilis & 4 & 1 \\
Molluscum contagiosum & 1 & \\
Chancroid, lymphogranuloma & & $0 \cdot 1$ \\
$\quad$ venereum, and granuloma & $0 \cdot 2$ & 2 \\
$\quad$ inguinale combined & & \\
\hline
\end{tabular}

Calculated from data kindly supplied by Dr J. H. Berrie

In this paper are considered those diseases that often present as genital discharges-namely, gonorrhoea, candidosis, trichomoniasis, and non-specific genital infection. In part 2, those diseases that present as genital or skin tumours, sores, or rashes will be considered. In Table 1 the $100 \%$ represented for gonorrhoea in 1974 comprised 38466 cases in men and 21288 cases in women treated in the clinics of England and Wales during that year.

\section{Gonorrhoea}

\section{PREVALENCE}

In 1974 in 24 European countries the World Health Organisation stated there were no fewer than 414343 reported cases of gonorrhoea-an increase of $22.6 \%$ on the 397883 cases noted in 1970-and there had been a continuing increase since 1960 . Throughout Europe there have been wide variations in reported incidence rates, largely because of differences in reporting and the number of cases treated privately. Incidence rates exceeding 200 per 100000 have recently been reported from Denmark, Finland, German Democratic Republic, Norway, and
Sweden. The highest reported rate was 483.5 per 100000 in Sweden in 1970 (Willcox, 1976).

The situation in Europe may be compared with that of the United States of America where in 1974 there were no fewer than 874161 reported cases giving an incidence of $420 \cdot 1$ per 100000 (American Social Health Association, 1975), and as four out of five cases are treated either privately or in military hospitals the actual number is thought to be between $2 \frac{1}{2}$ and three million cases.

Two recent statistical phenomena are of interest. One is the large reduction in the male: female ratio which is now less than $2: 1$ in several countries including England, Finland, Scotland, and Sweden; formerly ratios of up to 5:1 were encountered.

The other phenomenon is the recent check in the rate of gonorrhoea. This was first observed in Sweden, where it was heralded as being due to more intensive health education and some re-popularisation of the condom. However it has now extended to a number of countries including Denmark, Finland, German Democratic Republic, Yugoslavia, and also the USA (World Health Organisation, 1977). This epidemiological situation is attributed by some to the economic recession.

\section{IDEAL TREATMENT}

The ideal treatment for gonorrhoea is one that is one hundred per cent effective when given in a single dose as this has considerable epidemiological and administrative advantages. It must be available at reasonable cost and be free from toxic, allergic and microbiogenic side effects, including the development of microbial resistance not only of the gonococcus but of other pathogens. It should not be cross resistant with other antibiotics or encourage subsequent fungal overgrowth, and it should not mask acquired syphilis. It should also have a low incidence of post-treatment non-gonococcal urethritis.

Maximum therapeutic effect and minimal development of microbial resistance or fungal overgrowth are achieved by a regimen that gives a high initial serum level which rapidly declines after 12 hours. While some clinicians may prefer a drug which does not affect incubating syphilis, an agent which aborts it has considerable advantages for the patient and the community. The antibiotic should also not be one of the few agents available for more serious conditions.

\section{TREATMENT AGENTS}

There are many antibiotics or chemotherapeutic substances that are active against the gonococcus. These are the penicillins, the cephalosporins, the tetracyclines, chloramphenicol, thiamphenicol, erythromycin, oleandomycin, spiramycin, rifampicin, 
kanamycin, gentamicin, spectinomycin, and cotrimoxazole. At one time streptomycin was also effective but it is now virtually useless owing to resistance.

None of these agents is ideal. Benzyl penicillin, in combination with procaine, or ampicillin and related oral preparations are the antibiotics that have generally been used as they are non-toxic especially in pregnancy. They have the disadvantages of evoking allergy and that both a stepwise reduction in sensitivity and complete resistance may occur to them and the cephalosporins.

\section{PROBLEMS OF ALLERGY}

Allergy to penicillin is less important in venereal disease clinics as a history of previous penicillin administration and possible side effects is always taken and if hypersensitivity is suspected another drug is used. For example, in the USA in 1969, of 36048 patients questioned $6.6 \%$ claimed a sensitivity to penicillin and, of 26673 patients treated with penicillin $0.66 \%$ experienced reaction, the most usual being urticaria (Rudolph and Price, 1973). The incidence of anaphylaxis was $0.04 \%$ but there was only one death in 94655 patients. Allergy to other antibiotics used to treat gonorrhoea is uncommon.

PROBLEMS OF RESISTANCE

Experience with sulphonamides

In 1936 the treatment of gonorrhoea, by means of protracted courses of irrigations and washouts, changed dramatically with the introduction of the sulphonamides. With 10 to $20 \%$ of failures to these drugs with the dosages it was possible to give safely, the proportion of more resistant organisms gradually increased. This first became evident in 1942 in brothels in Naples where the prostitutes had been given a German sulphonamide Uleron, and eventually the effect of this group of drugs declined until treatment failed in three-quarters of the patients.

\section{Progressive resistance to penicillin}

When penicillin arrived clinicians wondered if this deterioration of effect would happen again. The process did occur but it developed slowly and was patchy geographically. The resultant resistance is still incomplete and penicillin can be used. Thus gonorrhoea in London could be cured with single doses of 150000 units of a repository penicillin 25 years ago, today a dose 16 times as great (that is, 2.4 megaunits of procaine penicillin) with probenecid is now given, while in some parts of the world 4.8 megaunits of procaine penicillin will give unacceptable results without probenecid.

The strains of gonococci that are less sensitive to penicillin commonly show complete resistance to streptomycin and this antibiotic has now become virtually useless for treating the disease. On a much smaller scale, lessened sensitivity has also been noted to some other antibiotics.

\section{Emergence of penicillinase-producing gonococci}

Origin and distribution As forecast in Seattle by Falkow et al. (1976) on the basis of plasmidintroduced resistance which had been observed with Haemophilus influenzae, a similar phenomenon of vital importance occurred early in 1977 when penicillinase-producing gonococci made their appearance in the Far East, the USA, and in Europe. Such organisms are completely resistant to penicillins and to the cephalosporins, however large the dose.

Most strains in the USA were originally imported from the Far East (Philippines) and the first two were found in patients in Maryland and California in February and April of 1976, respectively (Ashford et al., 1976; Center for Disease Control, 1976). By September, twelve cases had been encountered in seven states, 11 of which were linked to individuals who had recently returned from the Far East (Center for Disease Control, 1976).

About this time a case in a Ghanaian woman was reported from London (Philips, 1976) and between February and August 197645 cases of gonococca infection with penicillinase-producing gonococcio were encountered at Liverpool Royal Infirmary, and by October twenty-five others had been noted in the public health laboratories in Liverponl (Turner et al., 1976). Cases were also reported from other parts of the United Kingdom, from Singapore (imported from Thailand), Holland, Germany, Norway, and elsewhere. In prostitutes patronised by soldiers in the Philippines such strains were found to be widespread, and in Liverpool these strains accounted for $9 \%$ of the total isolates.

No epidemiological connection has so far been established between the American or Far Eastern strains and those of Liverpool, and indeed there are some differences - such as, size of plasmid, antibiotic sensitivity, auxotype, and transferability. Those in Liverpool have a larger plasmid and, unlike the American strains, are fairly sensitive to tetracycline and can be transferred in vitro to other organisms which suggests that the phenomenon may be arising simultaneously in more than one area.

Significance Should these plasmids prove stable the epidemiological significance could be profound. Increasing failure rates to treatment with the penicillins may be expected with an increased incidence of complications, particularly in high risk groups indulging in more frequent indiscriminate 
sexual exposure and in those persons who fail to attend for follow-up visits.

The situation could theoretically be countered by the general antibiotic monitoring of gonococcal isolates and by stringent post-treatment checks. These measures are not possible in areas where there are few facilities for culture.

Only when the problem can be shown to have reached significant proportions will a change in treatment be merited. This will involve the use of more expensive drugs (for example, spectinomycin or kanamycin) or the abandonment of single-dose treatments-for example, by using co-trimoxazole which gives less good results with gonococci less sensitive to penicillin (Evans and Churcher, 1976)with the likelihood of increased resistance as usage increases.

Penicillinase-resistant penicillins and cephalosporins (for example, cloxacillin) are not very effective against the gonococcus (Willcox, 1964). A new cephalosporin, cefuroxime, currently under investigation is promising but this, too, is likely to be expensive.

Spread of gonococcal resistance. From experience of the use of sulphonamides, penicillin, and streptomycin we have knowledge of the time scale of resistance. When the sulphonamides were introduced in 1937 they had a 10 to $25 \%$ resistance rate, but 12 years later $86 \%$ of treatments in London failed (Dunlop, 1949). Streptomycin gave better cure rates of between 97 and $98 \%$ in 1947-49 when first used but complete resistance to this antibiotic was found in London in $8.5 \%$ by 1951 . This figure had increased first to $14.9 \%$ and then to $31 \cdot 7 \%$ by 1966 15 years later, and it was forecast that it would fail in $85 \%$ of patients by 1971 (Willcox, 1970). This figure was virtually shown to be true in a small test series (Willcox, 1973). It thus took between 18 and 19 years before streptomycin became $31.7 \%$ ineffective and between 23 and 24 years to be completely so.

Penicillin was introduced in 1945 and it was 10 years before correlation between failure rates and lessened sensitivity was well established. Lessened sensitivity was encountered in some areas between 25 and 30 years later-for example, in Vietnam and Thailand-but until recently this was overcome by giving sufficient penicillin (and probenecid).

These experiences indicate that the increase in failure rates is at first almost imperceptible but once failures exceed 20 to $30 \%$ the drug can be expected to become virtually useless within five years. Once resistant organisms to a particular therapeutic agent have arisen they will continue to spread even if that agent is never used for treatment. Therefore unless the plasmid should prove to be unstable the useful life of penicillin in the treatment of gonorrhoea may be doomed. Indeed with the recent changes in human behaviour the process of spread may be expected to be more rapid than might have been envisaged from previous experience.

Recent experience with penicillinase producing organisms. In Liverpool the numbers of completely resistant isolates rose to about 80 and were individually exported to London, Essex, and other parts of the United Kingdom. However, with the network of clinics and the availability of more expensive drugs these strains have been gradually reduced and no new indigenous case has been encountered in Liverpool since November 1976. (One found in January 1977 was considered to be of Far Eastern origin as was the American series (Percival et al., 1976; Alergant et al., 1977, personal communication)).

Routine testing of the antibiotic sensitivity of gonococci has been instituted or continued in several London clinics. In the first four months of 1977 no case was encountered at the Middlesex Hospital (Catterall, 1977, personal communication) and only two $(0.4 \%)$ penicillinase-producing isolates were found in 469 tested at St Mary's Hospital.

It would thus appear either that this particular plasmid is unstable, or that the available facilities are sufficient to contain it-probably the former.

In the United States of America, as increasing numbers of strains are tested more penicillinase producers have been detected. By the end of January 1977 no fewer than 94 strains had been detected in 16 states and an exponential curve of detection could be plotted. The proportion of strains related to the Far East declined from $81 \%$ up to September 1976 to $18 \%$ in the most recent two months (Center for Disease Control, 1977), indicating that the strains had taken root (Fig. 1). Although 94 strains in relation to the overall size of the gonorrhoea problem in the USA seems insignificant there is nevertheless, as yet, no room for complacency.

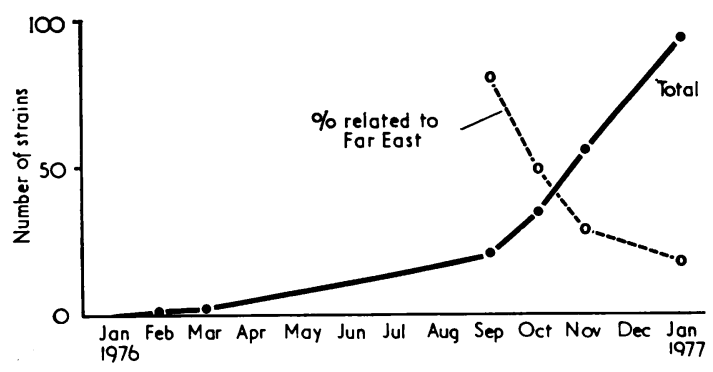

Fig. 1 Penicillinase-producing gonococci in the USA 
CURRENT RECOMMENDATIONS FOR

TREATMENT

Modifications to US schedules

The discovery of penicillinase-producing gonococci led to two changes in the recommendations of the United States Public Health Service (Table 2).

Table 2 Modifications to United States Public Health Service treatment schedules in non-pregnant patients

\begin{tabular}{llll}
\hline $\begin{array}{l}\text { Relative to } \\
\text { discovery of } \\
\text { PPNG }\end{array}$ & Before & After & Comment \\
\hline No allergy & $\begin{array}{l}\text { Procaine } \\
\text { penicillin plus } \\
\text { probenecid } \\
\text { or } \\
\text { ampicillin } \\
\text { plus probenecid }\end{array}$ & $\begin{array}{l}\text { 1. Procaine } \\
\text { penicillin plus } \\
\text { probenecid } \\
\text { Ampicillin } \\
\text { plus } \\
\text { probenecid }\end{array}$ & $\begin{array}{l}\text { 2. Less effective } \\
\text { May encourage } \\
\text { PPNG } \\
\text { Use in patients } \\
\text { who fear } \\
\text { needles and } \\
\text { who will return }\end{array}$ \\
$\begin{array}{l}\text { Suspect } \\
\text { penicillin }\end{array}$ & $\begin{array}{l}\text { Tetracycline } \\
\text { or } \\
\text { allergy }\end{array}$ & Tetracycline & $\begin{array}{l}\text { Loss of single } \\
\text { dose but complete } \\
\text { resistance could } \\
\text { arise to } \\
\text { spectinomycin }\end{array}$ \\
$\begin{array}{l}\text { PPNG or } \\
\text { treatment } \\
\text { failures } \\
\text { (and contacts) }\end{array}$ & - & Spectinomycin & $\begin{array}{l}\text { Reserve for this } \\
\text { important group }\end{array}$
\end{tabular}

PPNG Penicillinase-producing strains of Neisseria gonorrhoeae

In the treatment of non-pregnant patients with uncomplicated genital gonorrhoea penicillin was retained as the antibiotic of choice. Procaine penicillin 4.8 megaunits plus $1.0 \mathrm{~g}$ of probenecid had previously been given equal rating with ampicillin $3.5 \mathrm{~g}$ plus $1.0 \mathrm{~g}$ of probenecid. As the ampicillin schedule was slightly less effective and its use might have encouraged the further development of penicillinase-producing organisms, this order was reversed and the ampicillin schedule is now recommended only for those who fear injections and who can be expected to return for follow-up tests.

The second change was in the choice of an alternative to penicillin in persons with suspected penicillin hypersensitivity. Tetracycline in multiple doses $(1.5 \mathrm{~g}$ initially followed by $2.0 \mathrm{~g}$ a day for four days), which is cheap, had previously been recommended with the much more expensive spectinomycin in single injections of $2.0 \mathrm{~g}$ with equal priority first (co-trimoxazole has not long been generally available in the USA). As some strains of gonococci were resistant to spectinomycin, it was felt that these would become widespread if the drug was extensively used, so it was recommended that this antibiotic should be reserved strictly for patients known to be carrying penicillinase-producing gonococci, for treatment failures, pending the results of such testing, and the recent sexual contacts of both these groups (Henderson, 1976). Tetracycline, in spite of the disadvantages of the loss of a single dose therapy, became the first choice in cases of suspected penicillin hypersensitivity.

Thus until the incidence of penicillinase-producing gonococci becomes significant, the policy is to use penicillin to the full as long as it gives satisfactory results.

\section{Optimal treatment}

If these regimens are adopted in Europe the best options in uncomplicated cases of anogenital gonorrhoea could be those shown in Table 3 .

Table 3 Optimal treatment of gonorrhoea

\begin{tabular}{lll}
\hline & Non-pregnant & Pregnant \\
\hline $\begin{array}{l}\text { No penicillin } \\
\text { hypersensitivity }\end{array}$ & $\begin{array}{l}\text { Procaine penicillin } \\
\text { plus probenecid* or } \\
\text { ampicillin plus } \\
\text { probenecid* }\end{array}$ & $\begin{array}{l}\text { Procaine penicillin } \\
\text { plus probenecid* or } \\
\text { ampicillin plus } \\
\text { probenecid* }\end{array}$ \\
$\begin{array}{l}\text { Suspected penicillin } \\
\text { hypersensitivity }\end{array}$ & $\begin{array}{l}\text { Tetracycline* } \\
\text { co-trimoxozole }\end{array}$ & Erythromycin* \\
$\begin{array}{l}\text { Penicillinase- } \\
\text { producing isolates or } \\
\text { treatment failures } \\
\text { (and their contacts) }\end{array}$ & $\begin{array}{l}\text { Spectinomycin*, } \\
\text { kanamycin, } \\
\text { (co-trimoxazole) }\end{array}$ & $\begin{array}{l}\text { Erythromycin* } \\
\text { (cefuroxime) } \\
\text { (spectinomycin) }\end{array}$ \\
\hline (Spectinomycin) \\
(spectinomycin)
\end{tabular}

* Recommended by United States Public Health Service

If there is no evidence of penicillin hypersensitivity and no epidemiological suggestion that the gonococcus may produce penicillinase penicillin 4.8 megaunits in a single injection ( 2.4 megaunits will usually suffice in Europe) plus $1.0 \mathrm{~g}$ of probenecid or ampicillin $3.5 \mathrm{~g}$, plus $1.0 \mathrm{~g}$ of probenecid, may be given in a single oral dose to all patients. If there is suspicion of penicillin hypersensitivity tetracycline or cotrimoxazole can be given in single or multiple doses, or kanamycin, or possibly spectinomycin in single injections of $2.0 \mathrm{~g}$ in patients who are not pregnant. In pregnant women the options are likely to be less effective. Erythromycin ( $9.5 \mathrm{~g}$ over $4 \frac{1}{2}$ days) may be given in the first place although with poorer results than with other preparations. The injectable alternatives are the cephalosporin, cefazoline (although this should not be used for patients with a history of penicillin anaphylaxis as there can be cross allergenicity between the penicillins and cephalosporins), and spectinomycin-an aminoglycoside which although not known to affect the fetus adversely has been insufficiently evaluated in this regard.

If the patient has known penicillinase-producing gonococci, is a treatment failure or a sexual contact of one in either of these categories, spectinomycin is recommended as the drug of choice. If the patient is 
pregnant, erythromycin is the first choice with possibly the new penicillinase-resistant cephalosporin, cefuroxime (not to be given in cases suspected of previous anaphylaxis) the second choice, and spectinomycin as third choice.

\section{Lack of suitable injectable penicillins}

Although penicillin has remained the treatment agent of choice the physician is not being as well served with suitable cheap injectable preparations as he might (Table 4).

Table 4 Injectable penicillins for gonorrhoea

\begin{tabular}{ll}
\hline Injectable penicillin & Comments \\
\hline Crystalline penicillin G & $\begin{array}{l}\text { Needs lignocaine; probenecid has } \\
\text { to be taken half an hour before }\end{array}$
\end{tabular}

Procaine penicillin

Repository penicillins (PAM and benzathine)

Probenecid can be given simultaneously but this penicillin is increasingly more difficult to obtain. Available products not presuspended.

Risk of procaine reaction.

Of the three types of injectable penicillin, the longacting repository penicillins - such as, benzathine penicillin or procaine penicillin with aluminium monostearate (PAM) - used for the treatment of syphilis are not suitable for gonorrhoea because of the long period of low levels of penicillinaemia they provide which could encourage the spread of resistant organisms. Crystalline penicillin $G$ can be satisfactorily used in a single 5 megaunit intramuscular dose plus $1.0 \mathrm{~g}$ of probenecid by mouth, but the penicillin needs dissolving in $0.5 \%$ lignocaine and the probenecid has to be given half an hour before the injection; this is a disadvantage particularly in clinics where patients are already retained for a precautionary half-hour after injection.

The best option, in spite of the risk of procaine reaction, is procaine penicillin with which the probenecid can be given simultaneously, and yet in the UK there is only one imported product and this is not pre-suspended; 10 years ago there were six such products at least two of which were available already in suspension (Table 5).

Table 5 Procaine penicillin: declining availability in $U K$

\begin{tabular}{lll}
\hline 1966 & & 1976 \\
\hline Product & Manufacturer & \\
\cline { 1 - 2 } Avloprocil & ICI & Depocilline \\
Distaquaine & Dista* & $\begin{array}{l}\text { Available bulk buying only } \\
\text { (Mycofarm-Brocades) }\end{array}$ \\
$\begin{array}{l}\text { Duracillin } \\
\text { Lenticillin }\end{array}$ & Lilly & \\
Mylipen & M B* & \\
Prostabillin & Glaxo & \\
\hline
\end{tabular}

*Available as aqueous suspension

†Available also as oily suspension
Needs for the future

There is a need for an effective, non-toxic, nonallergenic, and cheap antibiotic which is penicillinase resistant for the treatment of gonorrhoea. The new penicillinase-resistant cephalosporin cefuroxime, offers hope for the future but it is still being evaluated and is unlikely to be cheap in the immediate future.

\section{Candidosis}

\section{PREVALENCE}

Candidiasis, or candidosis (thrush), is caused by a yeast-like fungus Candida albicans and is the commonest reason for genital discharge in the female; it is considerably more common than gonorrhoea (130 versus 100, Fig. 2). Many patients do not complain of the discharge which adheres to the vagina, but more often of irritation or burning. Thrush is not always sexually contracted in the female in whom for various reasons the condition may flourish. It does cause a balanitis in the male in whom approximately 14 cases are encountered per 100 cases of gonorrhoea.
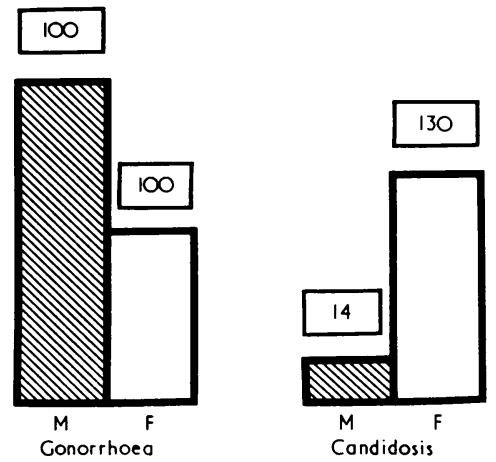

Fig. 2 Candidosis

TREATMENT

Available products

The Monthly Index of Medical Specialities (MIMS) in Britain lists 12 vaginal preparations for use in candidosis. Most are vaginal tablets or pessaries with an alternative cream, and two are vaginal gels (one with an alternative douche). There are 11 different manufacturers, two of which are sponsoring two products, while one agent is produced by two manufacturers (miconazole nitrate, Janssen and Ortho). In addition gentian (crystal) violet paint may be prescribed but today is seldom used.

With pessaries or vaginal tablets one or two are inserted nightly. The treatment periods vary from between three and six days (six tablets) with clotrimazole (Canesten) to 30 days with hydrargaphen (Penotrane). 
Those which seem to give particularly good results are vaginal tablets or pessaries containing clotrimazole, miconazole, nystatin, amphotericin B, candicidin, and natamycin. Owing to the shorter treatment time clotrimazole tends to be preferred (Table 6).

Table 6 Vaginal tablets or pessaries for candidosis

\begin{tabular}{|c|c|c|c|}
\hline Substance & $\begin{array}{l}\text { Proprietary } \\
\text { name }\end{array}$ & Manufacturer & $\begin{array}{l}\text { Days of } \\
\text { treatment }\end{array}$ \\
\hline $\begin{array}{l}\text { Clotrimazole } \\
\text { Miconazole* }\end{array}$ & $\begin{array}{l}\text { Canesten } \\
\text { Gyno-Daktarin } \\
\text { Monistat }\end{array}$ & $\begin{array}{l}\text { Bayer } \\
\text { Janssen } \\
\text { Ortho }\end{array}$ & $\begin{array}{l}3-6 \\
14\end{array}$ \\
\hline $\begin{array}{l}\text { Nystatin } \dagger \\
\text { Amphotericin } \ddagger \\
\text { Candicidin } \\
\text { Natamycin }\end{array}$ & $\begin{array}{l}\text { Nystan } \\
\text { Fungilin } \\
\text { Candeptin } \\
\text { Pimafucin }\end{array}$ & $\begin{array}{l}\text { Squibb } \\
\text { Squibb } \\
\text { Pharmax } \\
\text { Brocades }\end{array}$ & $\begin{array}{l}14 \\
14 \\
14 \\
21\end{array}$ \\
\hline
\end{tabular}

* As pessaries

$\dagger$ Tablets also available for oral use for bowel infections

Creams or ointments also available for each

Of those which the author has no experience or which are not considered as effective as the above are noxytiolin, nifuratel, chlordantoin, povidone-iodine, acid fuchsine, and hydrargaphen. Noxytiolin (Gynaflex) also has a short recommended treatment time (Table 7).

Table 7 Candidosis: other local drugs

\begin{tabular}{|c|c|c|c|c|}
\hline Substance & $\begin{array}{l}\text { Proprietary } \\
\text { name }\end{array}$ & Manufacturer & Form & $\begin{array}{l}\text { Days of } \\
\text { treatment }\end{array}$ \\
\hline $\begin{array}{l}\text { Noxytiolin } \\
\text { Nifuratel }\end{array}$ & $\begin{array}{l}\text { Gynaflex } \\
\text { Magmilor }\end{array}$ & $\begin{array}{l}\text { Gelstilch } \\
\text { Calmic }\end{array}$ & $\begin{array}{l}\text { Gel } \\
\text { Pessaries } \\
\text { plus oral } \\
\text { tablets }\end{array}$ & $\begin{array}{l}5-7 \\
10\end{array}$ \\
\hline Chlordantoin & Sporostacin & Ortho & $\begin{array}{l}\text { Cream } \\
\text { (twice daily) }\end{array}$ & )$^{14}$ \\
\hline $\begin{array}{l}\text { Povidone- } \\
\text { iodine }\end{array}$ & Betadine & Napp & $\begin{array}{l}\text { Gel and } \\
\text { douche }\end{array}$ & $14+$ \\
\hline Acid fuchsine & Pruvagol & Norgine & $\begin{array}{l}\text { Pessaries } \\
\text { and cream }\end{array}$ & 21 \\
\hline Hydrargaphen & Penotrane & WBP & Pessaries & 30 \\
\hline
\end{tabular}

Of the 12 antifungal preparations available three (nystatin, amphotericin, and nifuratel) are also supplied as oral tablets which can be used to reduce reinfection of the vagina from the bowel (Monthly Index of Medical Specialties, 1977).

\section{Needs for the future}

The length of the list of products is perhaps an indication of the unsatisfactory state of the treatment. The increasing confidence of one of the manufacturers in pressing for a three-day treatment is, it is hoped, based on their possession of a superior product. Nevertheless there is a need of a safe systemically-absorbed fungicide that could be used orally, or some biological substance that could reverse the situation which favours the growth of
C. albicans, and maintains an environment which is hostile to it.

\section{Trichomoniasis}

PREVALENCE

Trichomoniasis is often regarded as the most common cause of vaginal discharge. It is nearly as common as gonorrhoea in women ( 85 versus 100$)$ but is far less common (4 versus 100) in men (Fig 3).
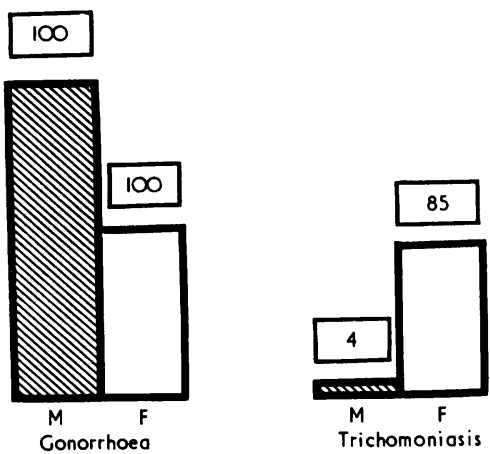

Fig. 3 Trichomoniasis

\section{TREATMENT}

Oral therapy

The oral treatment of trichomoniasis is a good example of pharmaceutical competition (Table 8).

Table 8 Oral treatment of trichomoniasis

\begin{tabular}{|c|c|c|c|c|c|c|}
\hline \multirow[t]{2}{*}{ Years } & \multicolumn{3}{|c|}{$\begin{array}{l}\text { Metronidazole (Flagyl) } \\
200 \mathrm{mg}\end{array}$} & \multicolumn{3}{|c|}{$\begin{array}{l}\text { Nimorazole } \\
\text { (Nitrimidazine Naxogin) } \\
250 \mathrm{mg}\end{array}$} \\
\hline & Total $\mathrm{g}$ & Tablets & Time (days) & Total $\mathrm{g}$ & Tablets & Time (days) \\
\hline $1958-69$ & $4 \cdot 2$ & 21 & 7 & - & - & - \\
\hline 1970 & & & & $3 \cdot 0$ & 12 & 6 \\
\hline 1971 & $\begin{array}{r}4 \cdot 2 \\
\text { or } 6 \cdot 0\end{array}$ & $\begin{array}{l}21 \\
30\end{array}$ & $\begin{array}{l}7 \\
5\end{array}$ & & & \\
\hline 1973 & $\begin{array}{r}4.2 \\
\text { or } 4.0\end{array}$ & $\begin{array}{l}21 \\
20^{*}\end{array}$ & $\begin{array}{l}7 \\
2\end{array}$ & $3 \cdot 0$ & 12 & $\begin{array}{l}1 \frac{1}{2} \\
\text { One dose }\end{array}$ \\
\hline 1976 & & & & $\begin{array}{r}2 \cdot 0 \\
\text { or } 3 \cdot 0\end{array}$ & $\begin{array}{r}8 \\
12\end{array}$ & \\
\hline 1977 & $\begin{array}{r}4 \cdot 0 \\
\text { or } 4 \cdot 2\end{array}$ & $\begin{array}{l}20^{*} \\
21\end{array}$ & $\begin{array}{l}2 \\
7\end{array}$ & $2 \cdot 0$ & 8 & One dose \\
\hline
\end{tabular}

Also

available $400 \mathrm{mg}$ tablets

$500 \mathrm{mg}$ tablets

Recommended schedules from MIMS

$* 800 \mathrm{mg}$ in morning, $1200 \mathrm{mg}$ at night

Until 1958 trichomoniasis was treated with innumerable vaginal tablets, pessaries, creams, ointments, or douches-the very number was a striking testimony to their ineffectiveness. Then, after not very impressive trials with aminitrozole used in the prevention of enterohepatitis in turkeys (Willcox, 1957), metronidazole (Flagyl is the proprietary name 
in Britain) was introduced and, as 21 tablets each of $200 \mathrm{mg}$ given thrice daily for one week cured $90-95 \%$ of patients, this became the standard treatment for a decade.

Its first rival appeared in 1970 in the shape of nimorazole (Naxogin) - and one $250 \mathrm{mg}$ twice daily for six days gave a satisfactory cure rate. Since then the manufacturers have increased the size of their doses and reduced the length of the course. Now the recommended regimens for metronidazole are $800 \mathrm{mg}$ in the morning and $1200 \mathrm{mg}$ at night for two days, while $200 \mathrm{mg}$ three times daily is retained as an alternative. A single dose of $2 \mathrm{~g}$ has been reported to give reasonably satisfactory results, but the makers themselves do not suggest this although they do supply $400 \mathrm{mg}$ and $200 \mathrm{mg}$ tablets. The manufacturers of nimorazole have introduced $500 \mathrm{mg}$ tablets and do recommend a single dose of $2 \mathrm{~g}$.

Today there is a tendency to emphasise the value of a single dose of $2.0 \mathrm{~g}$ which can be given to the patient under supervision. A newer product, tinidazole (Fasigyn) has been used in this way in Denmark (Korner and Jensen, 1976), apparently with success. More recently another imidazole compound carnidazole has been used (Notowicz et al., 1977) while ornidazole has been reported as being totally effective in Sweden (Sköld et al., 1977). However, the side effects in terms of fatigue and dizziness were much greater than with metronidazole, a drug from which, in the doses used, was remarkably free from side effects apart from the fact that candidosis might supervene after treatment.

Nifuratel is not sufficiently effective by itself without simultaneous local treatment.

\section{Local treatment}

In spite of the efficacy of systemic treatment and the unsatisfactory effects of local treatment a large list of preparations is still advertised for local use; at least nine preparations are available in Great Britain with treatment times varying between 3 and 56 days (Table 9).

These local preparations are widely used in pregnancy in which, certainly in the first trimester, the systemic drugs are avoided. Indeed, pregnancy is listed as a special precaution rather than a contraindication in the British list. Although there is little clinical evidence that metronidazole is harmful the possibility is not disproved.

\section{Needs for the future}

The pharmaceutical industry, in providing an acceptable cure rate with a single dose, has done all that can be expected of it and any further control of this condition lies firmly in the field of human behaviour rather than in that of pharmaceutical endeavour.
Table 9 Local preparations available for treatment of trichomoniasis

\begin{tabular}{|c|c|c|c|c|}
\hline $\begin{array}{l}\text { Proprietary } \\
\text { name }\end{array}$ & $\begin{array}{l}\text { Chemical } \\
\text { name }\end{array}$ & Manufacturer & Product & $\begin{array}{l}\text { Treatment } \\
\text { (days) }\end{array}$ \\
\hline Betadine & $\begin{array}{l}\text { Povidone- } \\
\text { iodine }\end{array}$ & Napp & Gel/douche & $14+$ \\
\hline Canesten & Clotrimazole & Bayer & $\begin{array}{l}\text { Tablet/ } \\
\text { cream }\end{array}$ & $3-6$ \\
\hline Floraquin & $\begin{array}{l}\text { Dihydro- } \\
\text { oxyquinoline }\end{array}$ & Searle & Pessary & $28-56$ \\
\hline Gynaflex & Noxytiolin & Gelstilch & Gel & $5-7$ \\
\hline Magmilor & Nifuratel & Calmic & $\begin{array}{l}\text { Pessary }+ \\
\text { oral tablets }\end{array}$ & 10 \\
\hline $\begin{array}{l}\text { Penotrane } \\
\text { Pimafucin }\end{array}$ & $\begin{array}{l}\text { Hydrargaphen } \\
\text { Natamycin }\end{array}$ & $\begin{array}{l}\text { WPB } \\
\text { Brocades }\end{array}$ & $\begin{array}{l}\text { Pessary } \\
\text { Tablet/ } \\
\text { cream }\end{array}$ & $\begin{array}{l}30 \\
21\end{array}$ \\
\hline $\begin{array}{l}\text { Pruvagol } \\
\text { SVC }\end{array}$ & $\begin{array}{l}\text { Acid fuchsine } \\
\text { Acetarsol }\end{array}$ & $\begin{array}{l}\text { Norgine } \\
\text { M \& B }\end{array}$ & $\begin{array}{l}\text { Pessary } \\
\text { Tablet }\end{array}$ & $\begin{array}{c}21 \\
\text { As necessary }\end{array}$ \\
\hline
\end{tabular}

The side effect of supervening vaginal thrush after treatment is not a criticism of the effective treatment of trichomoniasis but rather a reflection of the ecological situation relating to candidosis.

\section{Non-specific genital infection}

\section{INCIDENCE}

Non-specific genital infection is considerably more prevalent than gonorrhoea in men, Fig. $4(185$ versus 100 ): In men the term usually refers to nonspecific urethritis but the British figures also include an unknown number of cases of non-specific proctitis. There are many cases of non-specific genital infection relative to gonorrhoea in women (71 versus 100 ) but this figure comprises a mixture of cases of vaginal discharge (after gonorrhoea, trichomoniasis, candidosis, foreign body, and neoplasm have been excluded), of cervicitis, and the treated contacts of males with non-specific urethritis.

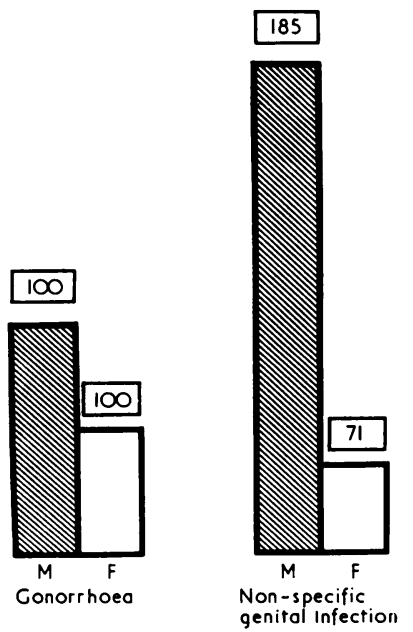

Fig. 4 Non-specific genital infection 


\section{TREATMENT}

Non-specific urethritis in the male

Some 30 to $40 \%$ of cases of non-specific urethritis in the male have been shown to be caused by Chlamydia but, except for reasons of research in some centres, tissue culture for such organisms is seldom available. Treatment is therefore empirical.

The results of following-up over 2000 of 2500 patients treated for non-specific urethritis with 27 regimens gives an overall failure rate of approximately 30\% (range 10.4-68.2\%) (Willcox, 1972; Willcox et al., 1975).

The most successful drugs were the tetracyclines with a $84 \%$ primary success rate $(15.9 \%$ failures). The range of failure varied from $10.4 \%$ with minocycline to $18.5 \%$ with tetracycline and chlortetracycline: doxycycline was not tested.

Next in order were spiramycin and oleandomycin with 20.3 to $22.4 \%$ failures, followed closely by co-trimoxazole, streptomycin plus sulphonamides, and erythromycin with $24 \cdot 4$ to $27 \cdot 7 \%$ failures.

Of the least effective drugs the sulphonamides without trimethoprim, penicillin, chloramphenicol, and spectinomycin plus sulphonamides gave a range of 37.0 to $44.1 \%$ failures, while low on the list with $46 \cdot 1$ to $66 \cdot 7 \%$ failures were streptomycin alone, metronidazole, novobiocin, nalidixic acid, and ampicillin. The failure rate of the last was virtually the same as with a placebo $(68 \cdot 2 \%)$.

From the above the following points emerge:

1. Tetracyclines give the best results,

2. The results obtained with co-trimoxazole are similar to earlier findings with streptomycin and sulphonamides,

3. Spectinomycin, which is an excellent drug for gonorrhoea, is ineffective in non-gonococcal urethritis,

4. Antitrichomonal drugs are also ineffective,

5. Ampicillin which is the antibiotic most often used by general practitioners is the least effective.

In the above series, however, a treatment lasting five to six days was that most often used. Some physicians from experience with Chlamydia, recommend two to three weeks of treatment with tetracyclines and the author is currently using a period of two weeks.

The treatment of Reiter's syndrome, which affects 0.5 to $1.0 \%$ of patients with non-gonococcal urethritis is beyond the scope of this paper.

\section{Non-specific proctitis in males}

Non-specific proctitis in men is another unsatisfactory condition which is diagnosed in male homosexuals usually by the presence of excessive numbers of leucocytes (15 or more per high power field) in a rectal smear, with or without signs of rectal discharge or proctitis, but without evidence of the gonococcus. The treatment is similar to that of non-specific urethritis.

\section{Non-specific urethritis in females}

Non-specific urethritis is rarely diagnosed in the female contacts of men with non-gonococcal urethritis, a cervicitis is more easily recognised. Such contacts, even without cervicitis, are often given a course of tetracycline. If this treatment course is extended beyond one week the possibility of activating vaginal thrush (itself a possible cause of nonspecific urethritis in the male) is enhanced and therefore fungicide pessaries may also be prescribed.

There is no firm evidence that treatment of the female contact is advantageous in preventing relapse in the male. This represents a significant and reprehensible gap in clinical research which can be resolved if dedication is sufficient.

\section{Non-specific vaginal discharge}

Vaginal discharge, after excluding known causes, tends to be treated with pessaries as for candidosis. In this group are discharges caused by Corynebacterium vaginale ( $H$. vaginalis), a sexually transmitted organism the pathogenicity of which is still not known. The organisms are found in profusion, in some epithelial cells (clue cells) in patients often with considerable chronic vaginal discharge. The discharge is characteristically typified by an absence of leucocytes and it has been suggested that $C$. vaginale represents an infection of the secretion rather than inflammation of the vaginal wall (Dunkelberg, 1974).

In its treatment chloramphenicol or tetracycline pessaries have been found of use (although often followed by vaginal thrush) as has tetracycline or ampicillin given orally. Sulphonamides, either locally or by mouth, have not been so effective (Harris, 1975) or only 'possibly so' (Rein and Chapel, 1975).

Pessaries or vaginal preparations on the commercial market in Great Britain, other than those used for trichomoniasis or thrush, and those containing stilboestrol or dienoestrol used for senile vaginitis, comprise acetic acid and oxyquinoline (Aci-JelOrtho), mixed sulphonamides (Sultrin-Ortho), acetarsol (SVC-M \& B) left over from the older treatment for trichomoniasis and neomycin (Tamporagan- $\mathrm{N}$-Camden). Pessaries containing chloramphenicol or oxytetracycline are no longer available.

\section{Needs for the future}

The immediate needs in this condition lie in the field of diagnosis and in the detection of asymptomatic 
forms of the various disease syndromes. Further research is required into the result of various treatments and treatment durations in cases of urethritis in which Chlamydia or other suspect organisms have been found and in their contacts which then can be more generally applied.

More research is required into the aetiology and causation of non-gonococcal urethritis and the relative roles of Chlamydia and other contending pathogens.

\section{References}

American Social Health Association (1975). Today's VD Control Problem. ASHA: New York.

Ashford, W. A., Golash, R. G., and Hemming, V. G. (1976) Penicillinase-producing Neisseria gonorrhoeae. Lancet, 2, 657-658.

Center for Disease Control (1976). Penicillinase-producing Neisseria gonorrhoeae. Morbidity and Mortality Weekly Report, 25, 262-307

Center for Disease Control (1977). Follow-up on antibiotic resistant Neisseria gonorrhoeae. Morbidity and Mortality Weekly Report, 26, 29.

Dunkelberg, W. E. (1974). A Bibliographic Review of Corynebacterium vaginale ( $H$. vaginalis). US Army Printing Office: Georgia.

Dunlop, E. M. C. (1949). Gonorrhoea and sulphonamides. British Journal of Venereal Diseases, 25, 81-83.

Evans, A. J., and Churcher, G. M. (1976). Letter: Penicillinaseproducing gonococci. Lancet, 2, 864.

Falkow, S., Elwell, L. P., de Graaft, J., de Heffron, F., and Mayer, L. (1976). In Sexually Transmitted Diseases, pp. 120-133. Edited by R. D. Catterall and C. S. Nicol. Academic Press: London.

Harris, J. R. W. (1975). Haemophilus vaginalis. In Recent Advances in the Sexually Transmitted Diseases, pp. 354-360. Edited by R. S. Morton and J. R. W. Harris. Churchill Livingstone: London.

Henderson, R. H. (1976). Expanded Guidelines Concerning Patients with Penicillinase-producing Neisseria gonorrhoeae. Center for Disease Control: Atlanta.

Korner, B., and Jensen, H. K. (1976). Sensitivity of Trichomonas vaginalis to metronidazole, tinidazole and nifuratel in vitro. British Journal of Venereal Diseases, 52, 404-408.
Monthly Index of Medical Specialties (1977). Volume 19, No. 3. Haymarket Publishing: London.

Notowicz, A., Stölz, E., and de Koning, G. A. J. (1977). First experiences with single-dose treatment of vaginal trichomoniasis with carnidazole (R25831). British Journal of Venereal Diseases, 53, 129-131.

Percival, A., Rowlands, J., Corkhill, J. E., Alergant, C. D., Arya, O. P., and Rees, E. (1976). Data presented to Medical Society for the Study of Venereal Diseases, 15 December.

Philips, I. (1976). $\beta$-lactamase-producing, penicillin-resistant gonococcus. Lancet, 2, 656-657.

Rein, M. F., and Chapel, T. A. (1975). Trichomoniasis, candidiasis and the minor venereal diseases. Clinical Obstetrics and Gynecology, 18, 73-88.

Rudolph, A. H., and Price, E. V. (1973). Penicillin reactions among patients in venereal disease clinics. A national survey. Journal of the American Medical Association, 223, 499-501.

Sköld, M., Gnarpe, H., and Hillström, L. (1977). Ornidazole: A new antiprotozoal compound for treatment of Trichomonas vaginalis infection. British Journal of Venereal Diseases, 53, 44-48.

Turner, G. C., Ratcliffe, J. G., and Anderson, D. (1976). Letter: Penicillinase-producing Neisseria gonorrhoeae. Lancet, 2, 793.

Willcox, R. R. (1957). Treatment of vaginal trichomoniasis with 2-acetylamino-5-nitrothiazole (aminitrozole) given orally. British Journal of Venereal Diseases, 33, 115-117.

Willcox, R. R. (1964). The newer penicillins in the treatment of gonorrhoea. Postgraduate Medical Journal, Supplement 40, 202207.

Willcox, R. R. (1970). A survey of problems in the antibiotic treatment of gonorrhoea. British Journal of Venereal Diseases, 46, 217-242.

Willcox, R. R. (1972). Triple tetracycline in the treatment of nongonococcal urethritis in males. British Journal of Venereal Diseases, 48, $137-140$.

Willcox, R. R. (1973). Chemotherapy of venereal disease. In Current Antibiotic Therapy. Edited by A. M. Geddes and J. D. Williams. Churchill Livingstone: Edinburgh.

Willcox, R. R. (1976). The Extent and Trends of the Sexually Transmitted Diseases in the WHO European Region. WHO Document ICP/VDT/001/RD1. WHO Regional Office for Europe: Copenhagen.

Willcox, R. R., Sparrow, R. W., and Fazluddin, C. M. (1975). Minocycline in the treatment of non-gonococcal urethritis. British Journal of Venereal Diseases, 51, 206-209.

World Health Organisation (1977). Report of Symposium on the Surveillance and Control of the Sexually Transmitted Diseases, Vienna, 21-25 September 1976. WHO Regional Office for Europe: Copenhagen. 